\title{
PENGUASAAN SOFT SKILLS MAHASISWA PROGRAM STUDI PENDIDIKAN TEKNOLOGI AGROINDUSTRI SEBAGAI CALON GURU VOKASIONAL DI ERA REVOLUSI INDUSTRI 4.0
}

\section{Soft Skills Mastery of Agroindustrial Technology Education Study Program Students as Future Teachers in the 4.0 Industrial Revolution}

\author{
Khansa Retno Dewi Kariyanti *, Sri Handayani, Mustika Nuramalia Handayani \\ Program Studi Pendidikan Teknologi Agroindustri, \\ Fakultas Pendidikan Teknologi dan Kejuruan, Universitas Pendidikan Indonesia \\ *khansardewi@student.upi.edu
}

\begin{abstract}
ABSTRAK
Mahasiswa Program Studi Pendidikan Teknologi Agroindustri sebagai calon guru di Sekolah Menengah Kejuruan Agriteknologi Pengolahan Hasil Pertanian dituntut mampu beradaptasi dan siap menghadapi tantangan global di era revolusi industri 4.0. Salah satu keterampilan penting yang perlu dikuasai yaitu soft skills. Penelitian ini bertujuan untuk mengetahui penguasaan soft skills antara mahasiswa yang belum dan sudah menempuh kegiatan magang di sekolah, program pengenalan lapangan satuan pendidikan (PPLSP) diantaranya keterampilan komunikasi tertulis dan lisan, kepemimpinan dan organisasi, bekerjasama, kreativitas, memecahkan masalah, belajar, literasi teknologi informasi komunikasi, kejujuran, dan percaya diri. Penelitian ini merupakan penelitian deskriptif kuantitatif yang melibatkan 60 orang mahasiswa. Pengumpulan data menggunakan angket yang terdiri atas 88 pernyataan self-report (pelaporan diri). Hasil penelitian menunjukkan bahwa penguasaan soft skills mahasiswa sebagai calon guru vokasional berada pada kategori sedang, sehingga perlu ditingkatkan pada beberapa indikator soft skills.
\end{abstract}

Kata kunci: guru vokasional, revolusi industri 4.0, soft skills

\begin{abstract}
Students of Agroindustrial Technology Education Study Program as future teachers at the Agricultural Product Processing Vocational High School are required to be able to adapt and be ready to face global challenges in the era of industrial revolution 4.0. One of the important skills that need to be mastered is soft skills. This study aimed to determine mastery of soft skills between students who have not and have taken internships at school including written and oral communication skills, leadership and organization, collaboration, creativity, problem solving, learning, information communication technological literacy, honesty, and confidence. This research was a quantitative descriptive study involving 60 students. Collecting data using a questionnaire consisting of 88 self-report statements. The results of the study indicated that soft skills mastery of students as future vocational teachers was in the medium category, so it needed to be improved on several soft skills indicators.
\end{abstract}

Keywords: vocational teacher, fourth industrial revolution, soft skills

\section{PENDAHULUAN}

Saat ini dunia telah memasuki era revolusi Industri generasi 4.0 yang ditandai dengan meningkatnya konektivitas, interaksi serta perkembangan sistem digital, kecerdasan artifisial, dan virtual. Dengan semakin konvergennya batas antara manusia, mesin dan sumber daya lainnya, teknologi informasi dan komunikasi tentu berimbas pula pada berbagai sektor kehidupan. Salah satunya yakni berdampak terhadap sistem pendidikan di Indonesia (Lase, 2019).

Era revolusi industri 4.0 secara tidak langsung telah mengubah cara pandang tentang pendidikan. Di era ini, guru dituntut menguasai keahlian, kemampuan beradaptasi dengan teknologi 
baru dan tantangan global. Literasi lama yang mengandalkan baca, tulis dan matematika harus diperkuat dengan mempersiapkan literasi baru yaitu literasi data, teknologi dan sumber daya manusia. Soft skills dalam era revolusi rndustri 4.0 termasuk ke dalam literasi Sumber Daya Manusia (SDM).

Dalam konteks pendidikan vokasional atau kejuruan dan persiapan guru kejuruan, integrasi soft skills maupun karakter dalam proses pendidikan memiliki peran strategis dalam upaya menghasilkan lulusan dan calon guru kejuruan yang profesional. Untuk menghasilkan lulusan yang memiliki kompetensi utuh tentu dibutuhkan calon guru yang memiliki soft skills handal disamping hard skills yang mantap. Pernyataan tersebut menggambarkan bahwa pentingnya soft skills dalam kesiapan mahasiswa menjadi calon guru kejuruan (Wagiran dkk., 2014).

Universitas Pendidikan Indonesia (UPI) sebagai universitas pelopor pendidikan di Indonesia yang menghasilkan tenaga pendidik khususnya guru menuntut mahasiswa untuk siap dalam menghadapi dunia kerja. Tak terkecuali Program Studi Pendidikan Teknologi Agroindustri (Prodi PTAg) yang merupakan salah satu program studi di Fakultas Pendidikan Teknologi dan Kejuruan (FPTK) UPI dan berperan dalam mencetak calon guru vokasional pada Kompetensi Keahlian Agriteknologi Pengolahan Hasil Pertanian. Mengingat bahwa sekolah kejuruan adalah sekolah yang menghasilkan lulusan siswa siap bekerja di dunia usaha maupun industri, maka dari itu mahasiswa Prodi PTAg dituntut untuk memiliki kemampuan mengajar yang baik serta memiliki karakter yang sesuai dengan sekolah kejuruan. Pengukuran Oleh karena itu, pengukuran soft skills mahasiswa perlu dilakukan. Menurut Widhiarso (2008) pengukuran soft skills akan menghasilkan sejumlah respon dari individu yang menunjukkan tingkat soft skills yang dimiliki, hasilnya akan mengarah pada karakteristik yang sifatnya internal dan manifes pada diri individu seperti dimensi afektif, motivasi, dan sikap.

Pengukuran soft skills dalam penelitian ini menggunakan metode self report. Penelitian ini serupa dengan penelitian Arnata dan Surjoseputro (2014) yang berjudul "Evaluasi Soft Skills dalam Pembelajaran Mahasiswa Baru di Fakultas Teknologi Pertanian Universitas Udayana", Asmarayandhie (2017) berjudul "Socialyze: Aplikasi Psikologi Dengan Metode Self-Report Untuk Indentifikasi Gaya dan Kemampuan Komunikasi", dan Setyantoko (2013) berjudul Kemampuan Soft Skills Guru Pendidikan Jasmani Olahraga dan Kesehatan SMA Negeri Se-Kabupaten Purworejo". Ketiga penelitan tersebut menghasilkan kemampuan soft skills yang baik dengan menggunakan pengukuran metode self report.

Berdasarkan observasi awal pada Program Pengenalan Lapangan Satuan Pendidikan (PPLSP) diketahui bahwa karakter mahasiswa prodi PTAg yang melaksanakan PPLSP mengalami penurunan dari angkatan sebelumnya, seperti dalam hal komunikasi, tanggungjawab, disiplin dan lain sebagainya. Hal ini senada dengan penelitian Wagiran (2013) bahwa beberapa keluhan pengelola KKN-PPL yaitu menurunnya kualitas mahasiswa calon guru terutama dalam hal inisiatif, keberanian bertindak, disiplin dan keakraban dengan guru. Hal ini menunjukkan bahwa soft skills maupun karakter yang dimiliki calon guru masih rendah. Oleh karenanya diperlukan upaya integrasi soft skills agar mahasiswa mengetahui soft skills dalam dirinya, sehingga bisa dilakukan pengembangan. Hal ini dilakukan agar calon guru kejuruan memiliki inisiatif tinggi, berani bertindak cepat dan cermat, disiplin, dan mampu menjalin komunikasi dengan baik.

Penelitian ini bertujuan untuk mengetahui penguasaan soft skills antara mahasiswa yang belum dan sudah menempuh kegiatan PPLSP sebagai calon guru vokasional di era revolusi industri 4.0. Penelitian ini diharapkan dapat menjadi bahan evaluasi dalam pengembangan soft skills mahasiswa calon guru vokasional di era revolusi industri 4.0.

\section{METODE}

Penelitian ini merupakan penelitan deskriptif kuantitatif dengan metode survei. Penelitian ini melibatkan 60 sampel yaitu 30 orang mahasiswa prodi pendidikan teknologi agroindustri angkatan 2016 yang sudah melaksanakan PPLSP dan 30 orang mahasiswa angkatan 2017 yang belum melaksanakan PPLSP. Pengambilan sampel menggunakan teknik purposive sampling yang didasarkan atas suatu pertimbangan tertentu (Hanief dan Himawanto, 2017). Teknik pengumpulan data yang digunakan adalah angket dimana pelaksanaannya dilakukan Pengambilan data dilakukan secara daring menggunakan google form. Angket yang digunakan terdiri atas 88 pernyataan self-report (laporan diri) 
dengan skala likert. Pernyataan-pernyataan tersebut merupakan indikator dari soft skills yang telah dikaji.

Sebelum melakukan pengambilan data sampel, instrumen diuji-cobakan terlebih dahulu pada responden yang memiliki karakteristik yang sama seperti sampel penelitian. Instrumen diuji cobakan kepada 30 orang mahasiswa angkatan 2015 yang sudah melaksanakan PPLSP. Uji coba instrumen dalam penelitian ini meliputi uji validitas dan reliabilitas. Terdapat 2 tahap uji validitas, yakni validitas konstruk oleh ahli (expert judgement) dan validitas empirik. Pengujian validitas empirik dan reliabilitas dilakukan dengan bantuan perangkat lunak IBM SPPS Statistics 24.0. Pada pengujian validitas empirik, nilai $r$ hitung yang dihasilkan lebih besar dari nilai $r$ tabel 0,36 . Selain itu, pada pengujian reliabilitas, angka yang dihasilkan pada setiap aspek keterampilan (soft skills) menunjukkan angka 0,986 (lebih besar dari $r$ tabel 0,7 ), yang artinya butir pernyataan dalam kuesioner dinyatakan reliabel. Analisis data yang digunakan dalam penelitan ini serupa dengan penelitian Setyantoko (2013) yakni analisis deskriptif kuantitatif. Data yang dianalisis merupakan data primer dari data self-report.

\section{HASIL DAN PEMBAHASAN}

\section{Penguasaan Komunikasi Tertulis Mahasiswa sebagai Calon Guru Vokasional}

Dalam penelitian ini, keterampilan komunikasi tertulis dijabarkan ke dalam 9 item pernyataan dalam kuesioner self-report (Tabel 1). Berdasarkan tabel 1, diketahui bahwa mahasiswa sebelum PPLSP belum menguasai kemampuan dalam mengkomunikasikan hasil inovasi pembelajaran kepada komunitas profesi sendiri secara tulisan dikarenakan belum menempuh kegiatan PPLSP. Dalam hal ini, suatu hasil inovasi pembelajaran akan didapatkan setelah adanya pengalaman mengajar dalam kegiatan PPLSP. Maka dari itu, dapat dipahami mengapa mahasiswa sebelum PPLSP belum menguasai kemampuan dalam mengkomunikasikan hasil inovasi pembelajaran.

Mahasiswa yang telah menempuh PPLSP memiliki kemampuan yang kurang dalam mengekspresikan pendapat dengan bahasa yang santun. Menurut Sibarani (dalam Nuryani, 2016) terdapat lima cara yang dapat dilakukan untuk membentuk kesantunan berbahasa diantaranya menerapkan prinsip kesopnan, menghindarkan kata-kata tabu, menggunakan eufimisme, menggunakan pilihan honorific yang tepat, dan menerapkan tindak tutur tidak langsung. Selain itu, sikap empatik dan santun dapat diaplikasikan dengan cara melakukan kritik, teguran, dan nasehat. Bahasa menjadi solusi alternatif dalam menyampaikan kritik, teguran, dan nasehat tersebut (Janawi, 2011).

Tabel 1. Penguasaan Keterampilan (soft skills) Komunikasi Tertulis Mahasiswa Prodi PTAg Untuk Menjadi Guru Vokasi di Era Revolusi Industri 4.0

\begin{tabular}{|c|c|c|c|c|}
\hline \multicolumn{2}{|c|}{ Pernyataan } & \multirow{3}{*}{$\begin{array}{l}\begin{array}{l}\text { Jumlah } \\
\text { (orang) }\end{array} \\
3 \\
5\end{array}$} & \multirow{2}{*}{$\begin{array}{l}\text { Angkatan } \\
2017 \\
\end{array}$} & \multirow{3}{*}{$\begin{array}{l}\text { Kategori } \\
\text { Tinggi }\end{array}$} \\
\hline \multirow{6}{*}{ a } & \multirow{6}{*}{$\begin{array}{l}\text { Saya Mampu } \\
\text { Menjalin Komunikasi } \\
\text { Yang Efektif Secara } \\
\text { Tertulis Baik Dengan } \\
\text { Warga Sekolah } \\
\text { Maupun Masyarakat }\end{array}$} & & & \\
\hline & & & 2016 & \\
\hline & & 22 & 2017 & \multirow{2}{*}{ Sedang } \\
\hline & & 20 & 2016 & \\
\hline & & 5 & 2017 & \multirow[b]{2}{*}{ Rendah } \\
\hline & & 5 & 2016 & \\
\hline \multirow{6}{*}{$b$} & \multirow{6}{*}{\begin{tabular}{l}
\multicolumn{1}{c}{ Saya Mampu } \\
Mengekspresikan \\
Pendapat Atau \\
Perasaan Dengan \\
Bahasa Yang Santun
\end{tabular}} & 6 & 2017 & \multirow{2}{*}{ Tinggi } \\
\hline & & 9 & 2016 & \\
\hline & & 20 & 2017 & \multirow{2}{*}{ Sedang } \\
\hline & & 11 & 2016 & \\
\hline & & 4 & 2017 & \multirow{2}{*}{ Rendah } \\
\hline & & 10 & 2016 & \\
\hline \multirow{6}{*}{ c } & \multirow{6}{*}{\begin{tabular}{l}
\multicolumn{1}{c}{ Saya Mampu } \\
Mengekspresikan \\
Pendapat Atau \\
Perasaan Dengan \\
Jelas
\end{tabular}} & 2 & 2017 & \multirow{2}{*}{ Tinggi } \\
\hline & & 7 & 2016 & \\
\hline & & 24 & 2017 & \multirow[b]{2}{*}{ Sedang } \\
\hline & & 17 & 2016 & \\
\hline & & 4 & 2017 & \\
\hline & & 6 & 2016 & Rendah \\
\hline \multirow{5}{*}{$d$} & \multirow{5}{*}{\begin{tabular}{l}
\multicolumn{1}{c}{ Saya Mampu } \\
Mengekspresikan \\
Pendapat Atau \\
Perasaan Dengan
\end{tabular}} & 10 & 2017 & \multirow{2}{*}{ Tinggi } \\
\hline & & 8 & 2016 & \\
\hline & & 12 & 2017 & \multirow{3}{*}{$\begin{array}{l}\text { Sedang } \\
\text { Rendah }\end{array}$} \\
\hline & & 18 & 2016 & \\
\hline & & 8 & 2017 & \\
\hline
\end{tabular}




\begin{tabular}{|c|c|c|c|c|}
\hline \multicolumn{2}{|c|}{ Pernyataan } & $\begin{array}{l}\text { Jumlah } \\
\text { (orang) }\end{array}$ & Angkatan & Kategori \\
\hline & $\begin{array}{l}\text { Bahasa Yang Mudah } \\
\text { Dipahami Orang Lain }\end{array}$ & 4 & 2016 & \\
\hline \multirow{6}{*}{ e } & \multirow{6}{*}{\begin{tabular}{l}
\multicolumn{1}{c}{ Saya Mampu } \\
Berkomunikasi \\
Melalui Media \\
Nirmassa Dalam \\
Rangka \\
Meningkatkan \\
Kualitas \\
Pembelajaran
\end{tabular}} & 1 & 2017 & \multirow{2}{*}{ Tinggi } \\
\hline & & 6 & 2016 & \\
\hline & & 25 & 2017 & \multirow{3}{*}{ Sedang } \\
\hline & & 21 & 2016 & \\
\hline & & 4 & 2017 & \\
\hline & & 3 & 2016 & Rendah \\
\hline \multirow{6}{*}{$f$} & \multirow{6}{*}{\begin{tabular}{l}
\multicolumn{1}{c}{ Saya Mampu } \\
Berkomunikasi \\
Melalui Media Massa \\
Dalam Rangka \\
Meningkatkan \\
Kualitas \\
Pembelajaran
\end{tabular}} & 3 & 2017 & \multirow{2}{*}{ Tinggi } \\
\hline & & - & 2016 & \\
\hline & & 24 & 2017 & \multirow{2}{*}{ Sedang } \\
\hline & & 25 & 2016 & \\
\hline & & 3 & 2017 & \multirow[b]{2}{*}{ Rendah } \\
\hline & & 5 & 2016 & \\
\hline \multirow{6}{*}{$g$} & \multirow{6}{*}{\begin{tabular}{l}
\multicolumn{1}{c}{ Saya Mampu } \\
Mengkomunikasi-kan \\
Hasil Inovasi \\
Pembelajaran \\
Kepada Komunitas \\
Profesi Sendiri \\
Secara Tulisan
\end{tabular}} & 6 & 2017 & \multirow{2}{*}{ Tinggi } \\
\hline & & 3 & 2016 & \\
\hline & & 15 & 2017 & \multirow{2}{*}{ Sedang } \\
\hline & & 24 & 2016 & \\
\hline & & 9 & 2017 & \multirow[b]{2}{*}{ Rendah } \\
\hline & & 3 & 2016 & \\
\hline \multirow{6}{*}{$\mathrm{h}$} & \multirow{6}{*}{\begin{tabular}{l}
\multicolumn{2}{c}{ Saya Mampu } \\
Mengekspresikan \\
Ide-Ide Secara \\
Tulisan Dengan \\
Penuh Keyakinan
\end{tabular}} & 7 & 2017 & \multirow{2}{*}{ Tinggi } \\
\hline & & 6 & 2016 & \\
\hline & & 16 & 2017 & \multirow{2}{*}{ Sedang } \\
\hline & & 16 & 2016 & \\
\hline & & 7 & 2017 & \multirow{2}{*}{ Rendah } \\
\hline & & 7 & 2016 & \\
\hline \multirow{6}{*}{$\mathrm{i}$} & \multirow{6}{*}{$\begin{array}{l}\quad \text { Saya Mampu } \\
\text { Mengekspresikan } \\
\text { Ide-lde Secara } \\
\text { Tulisan Dengan } \\
\text { Bahasa Yang Jelas }\end{array}$} & 8 & 2017 & \multirow{2}{*}{ Tinggi } \\
\hline & & 4 & 2016 & \\
\hline & & 18 & 2017 & \multirow{2}{*}{ Sedang } \\
\hline & & 20 & 2016 & \\
\hline & & 4 & 2017 & \multirow{2}{*}{ Rendah } \\
\hline & & 6 & 2016 & \\
\hline
\end{tabular}

\section{Penguasaan Komunikasi Lisan Mahasiswa sebagai calon Guru Vokasional}

Keterampilan (soft skills) komunikasi lisan dijabarkan ke dalam 13 item pernyataan dalam kuesioner self-report (Tabel 2).

Tabel 2. Penguasaan Keterampilan (soft skills) Komunikasi Lisan Mahasiswa Prodi PTAg Untuk Menjadi Guru Vokasi di Era Revolusi Industri 4.0

\begin{tabular}{|c|c|c|c|c|c|c|c|c|c|}
\hline & Pernyataan & $\begin{array}{l}\text { Jumlah } \\
\text { (orang) }\end{array}$ & Angkatan & Kategori & & Pernyataan & $\begin{array}{l}\text { Jumlah } \\
\text { (orang) }\end{array}$ & Angkatan & Kategori \\
\hline \multirow[t]{6}{*}{ a } & Saya Mampu & 6 & 2017 & \multirow[t]{2}{*}{ Tinggi } & \multirow[t]{6}{*}{$g$} & \multirow{6}{*}{$\begin{array}{l}\text { Saya Mampu } \\
\text { Berkomunikasi } \\
\text { Dengan Teman } \\
\text { Sejawat Dan } \\
\text { Komunitas IImiah } \\
\text { Lainnya Secara } \\
\text { Efektif }\end{array}$} & 4 & 2017 & \multirow[t]{2}{*}{ Tinggi } \\
\hline & Menyatakan & 5 & 2016 & & & & 7 & 2016 & \\
\hline & Ide, Gagasan & 20 & 2017 & \multirow[t]{2}{*}{ Sedang } & & & 17 & 2017 & \multirow[t]{2}{*}{ Sedang } \\
\hline & Maupun & 16 & 2016 & & & & 19 & 2016 & \\
\hline & Pikiran Secara & 4 & 2017 & \multirow[t]{2}{*}{ Rendah } & & & 9 & 2017 & \multirow[t]{2}{*}{ Rendah } \\
\hline & $\begin{array}{l}\text { Jelas Dengan } \\
\text { Alur Yang } \\
\text { Logis }\end{array}$ & 9 & 2016 & & & & 4 & 2016 & \\
\hline \multirow[t]{3}{*}{ b } & Saya Mampu & 5 & 2017 & \multirow[t]{2}{*}{ Tinggi } & \multirow[t]{3}{*}{$\mathrm{h}$} & \multirow{3}{*}{$\begin{array}{l}\text { Saya Mampu } \\
\text { Berkomunikasi } \\
\text { Dengan Orang Tua }\end{array}$} & 2 & 2017 & \multirow[t]{2}{*}{ Tinggi } \\
\hline & Menyatakan & 6 & 2016 & & & & 2 & 2016 & \\
\hline & & 21 & 2017 & Sedang & & & 24 & 2017 & Sedang \\
\hline
\end{tabular}


Khansa Retno Dewi Kariyanti, Sri Handayani, Mustika Nuramalia Handayani/ EDUFORTECH 6 (2) 2021

\begin{tabular}{|c|c|c|c|c|c|c|c|c|c|}
\hline & Pernyataan & $\begin{array}{l}\text { Jumlah } \\
\text { (orang) }\end{array}$ & Angkatan & Kategori & & Pernyataan & $\begin{array}{l}\text { Jumlah } \\
\text { (orang) }\end{array}$ & Angkatan & Kategori \\
\hline & \multirow{3}{*}{$\begin{array}{l}\text { Maupun } \\
\text { Pikiran Secara } \\
\text { Jelas Dengan } \\
\text { Alur Yang } \\
\text { Sistematis }\end{array}$} & 17 & 2016 & & & \multirow{3}{*}{$\begin{array}{l}\text { Peserta Didik Dan } \\
\text { Masyarakat Secara } \\
\text { Efektif Mengenai } \\
\text { Program } \\
\text { Pembelajaran Dan } \\
\text { Kemajuan Peserta } \\
\text { Didik }\end{array}$} & 20 & 2016 & \\
\hline & & 4 & 2017 & \multirow[t]{2}{*}{ Rendah } & & & 4 & 2017 & \multirow[t]{2}{*}{ Rendah } \\
\hline & & 7 & 2016 & & & & 8 & 2016 & \\
\hline \multirow[t]{9}{*}{ c } & \multirow{9}{*}{$\begin{array}{l}\text { Saya Mampu } \\
\text { Menjalin } \\
\text { Komunikasi } \\
\text { Yang Efektif } \\
\text { Secara Lisan } \\
\text { Baik Dengan } \\
\text { Warga } \\
\text { Sekolah } \\
\text { Maupun } \\
\text { Masyarakat }\end{array}$} & 2 & 2017 & \multirow[t]{2}{*}{ Tinggi } & \multirow[t]{9}{*}{$\mathrm{i}$} & \multirow{9}{*}{$\begin{array}{l}\text { Saya Mampu } \\
\text { Membujuk Orang } \\
\text { Tua Peserta Didik } \\
\text { Dan Masyarakat } \\
\text { Untuk Turut } \\
\text { Berikutserta Dalam } \\
\text { Program } \\
\text { Pembelajaran } \\
\text { Mengatasi Kesulitan } \\
\text { Belajar Peserta Didik }\end{array}$} & 8 & 2017 & \multirow[t]{2}{*}{ Tinggi } \\
\hline & & 6 & 2016 & & & & 6 & 2016 & \\
\hline & & 22 & 2017 & \multirow[t]{2}{*}{ Sedang } & & & 15 & 2017 & \multirow[t]{2}{*}{ Sedang } \\
\hline & & 22 & 2016 & & & & 18 & 2016 & \\
\hline & & 6 & 2017 & \multirow[t]{5}{*}{ Rendah } & & & 7 & 2017 & \multirow[t]{5}{*}{ Rendah } \\
\hline & & 2 & 2016 & & & & 6 & 2016 & \\
\hline & & & & & & & & & \\
\hline & & & & & & & & & \\
\hline & & & & & & & & & \\
\hline \multirow[t]{6}{*}{ d } & \multirow{6}{*}{$\begin{array}{l}\text { Saya Mampu } \\
\text { Memahami } \\
\text { Kepribadian } \\
\text { Dan Karakter } \\
\text { Siswa Dengan } \\
\text { Baik }\end{array}$} & 3 & 2017 & \multirow[t]{2}{*}{ Tinggi } & \multirow[t]{6}{*}{ j } & \multirow{6}{*}{$\begin{array}{l}\text { Saya Mampu } \\
\text { Mengkomunikasikan } \\
\text { Hasil Inovasi } \\
\text { Pembelajaran } \\
\text { Kepada Komunitas } \\
\text { Profesi Sendiri } \\
\text { Secara Lisan }\end{array}$} & 6 & 2017 & \multirow[t]{2}{*}{ Tinggi } \\
\hline & & 4 & 2016 & & & & 3 & 2016 & \\
\hline & & 25 & 2017 & \multirow[t]{2}{*}{ Sedang } & & & 19 & 2017 & \multirow[t]{2}{*}{ Sedang } \\
\hline & & 20 & 2016 & & & & 23 & 2016 & \\
\hline & & 2 & 2017 & \multirow[t]{2}{*}{ Rendah } & & & 5 & 2017 & \multirow[t]{2}{*}{ Rendah } \\
\hline & & $\overline{6}$ & 2016 & & & & 4 & 2016 & \\
\hline \multirow[t]{6}{*}{ e } & Saya Mampu & 10 & 2017 & \multirow[t]{2}{*}{ Tinggi } & \multirow[t]{6}{*}{$\mathrm{k}$} & \multirow{6}{*}{$\begin{array}{l}\text { Saya Mampu } \\
\text { Mengekspresikan } \\
\text { Ide-Ide Secara Lisan } \\
\text { Dengan Penuh } \\
\text { Keyakinan }\end{array}$} & 8 & 2017 & Tinggi \\
\hline & Berkomunikasi & 9 & 2016 & & & & 7 & 2016 & \\
\hline & Dengan & 17 & 2017 & Sedang & & & 18 & 2017 & Sedang \\
\hline & Teman & 20 & 2016 & & & & 21 & 2016 & \\
\hline & Sejawat Dan & 3 & 2017 & Rendah & & & 4 & 2017 & Rendah \\
\hline & $\begin{array}{l}\text { Komunitas } \\
\text { Ilmiah Lainnya } \\
\text { Secara } \\
\text { Santun }\end{array}$ & 1 & 2016 & & & & 2 & 2016 & \\
\hline $\mathbf{f}$ & Saya Mampu & 6 & 2017 & Tinggi & I & Saya Mampu & 7 & 2017 & Tinggi \\
\hline & Berkomunikasi & 7 & 2016 & & & Mengekspresikan & 4 & 2016 & \\
\hline & Dengan & 20 & 2017 & Sedang & & Ide-Ide Secara Lisan & 19 & 2017 & Sedang \\
\hline & Teman & 16 & 2016 & & & Dengan Bahasa & 20 & 2016 & \\
\hline & Sejawat Dan & 4 & 2017 & Rendah & & Yang Jelas & 4 & 2017 & Rendah \\
\hline & $\begin{array}{l}\text { Komunitas } \\
\text { Ilmiah Lainnya }\end{array}$ & 7 & 2016 & & & & 6 & 2016 & \\
\hline & Secara & & & & & & & & \\
\hline & & & & & & & & & \\
\hline
\end{tabular}

Sebagian besar mahasiswa sebelum dan setelah PPLSP tidak menguasai kemampuan berkomunikasi secara efektif dan menyampaikan pendapat dengan alur yang logis, padahal sebagian besar mahasiswa sebelum maupun setelah PPLSP merupakan anggota organisasi BEM (Badan Eksekutif Mahasiswa) maupun UKM (Unit Kegiatan Mahasiswa). Dimana menurut Haryati (2015) manfaat mengikuti kegiatan UKM dalam mengasah kemampuan lisan antara lain melatih keberanian untuk mengemukakan pendapat dan melatih berkomunikasi yang baik dengan orang lain. Pernyataan tersebut berbanding terbalik dengan keadaan kemampuan mahasiswa sebelum PPLSP.

Terdapat beberapa faktor yang mempengaruhi keahlian komunikasi guru dan calon guru. Sendana dan Tandikombong (2019) dalam penelitiannya memaparkan bahwa faktor-faktor yang mempengaruhi keahlian komunikasi guru (dan calon guru) diantaranya: a) kurangnya wawasan guru tentang kompetensi diri, kompetensi sosial dan wawasan pedagogic, b) kurangnya keyakinan dan kesadaran akan profesi yang digelutinya, c) banyaknya rutinitas di luar sekolah yang menyita waktu guru, d) minimnya program-program pengembangan wawasan dan keterampilan yang diikuti oleh guru, e) penerapan tata tertib dan peraturan yang kurang tegas di sekolah.

\section{Penguasaan Kepemimpinan dan Organisasi Mahasiswa}

Keterampilan (soft skills) kepemimpinan dan organisasi dijabarkan ke dalam 15 item pernyataan dalam kuesioner self-report (Tabel 3). 
Tabel 3. Penguasaan Keterampilan (soft skills) Kepimpinan dan Organisasi Mahasiswa Prodi PTAg Untuk Menjadi Guru Vokasi di Era Revolusi Industri 4.0

\begin{tabular}{|c|c|c|c|c|c|c|c|c|c|}
\hline \multicolumn{2}{|r|}{ Pernyataan } & $\begin{array}{l}\text { Jumlah } \\
\text { (orang) }\end{array}$ & Angkatan & Kategori & \multicolumn{2}{|r|}{ Pernyataan } & \multirow{2}{*}{$\begin{array}{c}\begin{array}{c}\text { Jumlah } \\
\text { (orang) }\end{array} \\
1\end{array}$} & \multirow{2}{*}{$\begin{array}{c}\text { Angkatan } \\
2017\end{array}$} & \multirow{2}{*}{$\begin{array}{c}\text { Kategori } \\
\text { Tinggi }\end{array}$} \\
\hline $\mathbf{a}$ & Saya Memiliki & 3 & 2017 & \multirow[t]{2}{*}{ Tinggi } & \multirow[t]{6}{*}{ j } & \multirow{6}{*}{$\begin{array}{l}\text { Saya } \\
\text { Mampumemberikan } \\
\text { Dukungan Pada } \\
\text { Siswa Dalam } \\
\text { Pengembangan } \\
\text { Kemampuan } \\
\text { Kreativitas Siswa }\end{array}$} & & & \\
\hline & Jiwa & 2 & 2016 & & & & 10 & 2016 & \\
\hline & Kepemimpinan & 19 & 2017 & \multirow[t]{2}{*}{ Sedang } & & & 23 & 2017 & \multirow[t]{2}{*}{ Sedang } \\
\hline & \multirow{3}{*}{$\begin{array}{l}\text { Tidak Otoriter } \\
\text { Dalam Bekerja }\end{array}$} & 26 & 2016 & & & & 16 & 2016 & \\
\hline & & 8 & 2017 & \multirow[t]{2}{*}{ Rendah } & & & 6 & 2017 & \multirow[t]{2}{*}{ Rendah } \\
\hline & & 2 & 2016 & & & & 4 & 2016 & \\
\hline \multirow[t]{6}{*}{ b } & \multirow{6}{*}{$\begin{array}{l}\text { Saya Memiliki } \\
\text { Jiwa } \\
\text { Kepemimpinan } \\
\text { Profesional Dalam } \\
\text { Bekerja }\end{array}$} & 8 & 2017 & \multirow[t]{2}{*}{ Tinggi } & \multirow[t]{6}{*}{$\mathrm{k}$} & \multirow{6}{*}{$\begin{array}{l}\text { Membantu Siswa } \\
\text { Untuk Melatih } \\
\text { Kemandirian Dalam } \\
\text { Pengembangan } \\
\text { Kreativitas Siswa }\end{array}$} & 3 & 2017 & \multirow[t]{2}{*}{ Tinggi } \\
\hline & & 8 & 2016 & & & & 10 & 2016 & \\
\hline & & 18 & 2017 & \multirow[t]{2}{*}{ Sedang } & & & 22 & 2017 & \multirow[t]{2}{*}{ Sedang } \\
\hline & & 19 & 2016 & & & & 17 & 2016 & \\
\hline & & 4 & 2017 & \multirow[t]{2}{*}{ Rendah } & & & 5 & 2017 & \multirow[t]{2}{*}{ Rendah } \\
\hline & & 3 & 2016 & & & & 3 & 2016 & \\
\hline \multirow[t]{6}{*}{ c } & Saya Memiliki & 9 & 2017 & \multirow[t]{2}{*}{ Tinggi } & \multirow[t]{6}{*}{ I } & \multirow{6}{*}{$\begin{array}{l}\text { Saya Selalu } \\
\text { Memberikan } \\
\text { Apresiasi Terhadap } \\
\text { Kemajuan Belajar } \\
\text { Siswa }\end{array}$} & 7 & 2017 & \multirow[t]{2}{*}{ Tinggi } \\
\hline & Jiwa & 10 & 2016 & & & & - & 2016 & \\
\hline & Kepemimpinan & 13 & 2017 & \multirow[t]{2}{*}{ Sedang } & & & 19 & 2017 & \multirow[t]{2}{*}{ Sedang } \\
\hline & Bertanggungjawab & 11 & 2016 & & & & 25 & 2016 & \\
\hline & Dalam Bekerja & 8 & 2017 & \multirow[t]{2}{*}{ Rendah } & & & 4 & 2017 & \multirow[t]{2}{*}{ Rendah } \\
\hline & & 9 & 2016 & & & & 5 & 2016 & \\
\hline
\end{tabular}

\begin{tabular}{|c|c|c|c|c|}
\hline \multicolumn{2}{|r|}{ Pernyataan } & Jumlah (orang) & Angkatan & Kategori \\
\hline \multirow[t]{6}{*}{ d } & \multirow{6}{*}{$\begin{array}{l}\text { Saya Berani Membuat Keputusan Seputar } \\
\text { Pendidikan Maupun Di Luar Bidang } \\
\text { Pendidikan }\end{array}$} & 3 & 2017 & \multirow[t]{2}{*}{ Tinggi } \\
\hline & & 3 & 2016 & \\
\hline & & 19 & 2017 & \multirow[t]{2}{*}{ Sedang } \\
\hline & & 23 & 2016 & \\
\hline & & 8 & 2017 & \multirow[t]{2}{*}{ Rendah } \\
\hline & & 4 & 2016 & \\
\hline \multirow[t]{6}{*}{ e } & \multirow{6}{*}{$\begin{array}{l}\text { Saya Siap Menghadapi Resiko Apapun Dari } \\
\text { Keputusan Yang Telah Saya Buat }\end{array}$} & 10 & 2017 & \multirow[t]{2}{*}{ Tinggi } \\
\hline & & 9 & 2016 & \\
\hline & & 12 & 2017 & \multirow[t]{2}{*}{ Sedang } \\
\hline & & 12 & 2016 & \\
\hline & & 8 & 2017 & \multirow[t]{2}{*}{ Rendah } \\
\hline & & 9 & 2016 & \\
\hline \multirow[t]{6}{*}{ g } & \multirow{6}{*}{$\begin{array}{l}\text { Saya Menunjukkan Praktek Kepemimpinan } \\
\text { Dan Berorganisasi }\end{array}$} & 5 & 2017 & \multirow[t]{2}{*}{ Tinggi } \\
\hline & & 9 & 2016 & \\
\hline & & 20 & 2017 & \multirow[t]{2}{*}{ Sedang } \\
\hline & & 15 & 2016 & \\
\hline & & 5 & 2017 & \multirow[t]{2}{*}{ Rendah } \\
\hline & & 6 & 2016 & \\
\hline \multirow[t]{6}{*}{$\mathbf{h}$} & \multirow{6}{*}{$\begin{array}{l}\text { Saya Mengikuti Kegiatan Organisasi Di } \\
\text { Sekolah Dan Atau Di Luar Sekolah }\end{array}$} & 7 & 2017 & \multirow[t]{2}{*}{ Tinggi } \\
\hline & & 8 & 2016 & \\
\hline & & 16 & 2017 & \multirow[t]{2}{*}{ Sedang } \\
\hline & & 16 & 2016 & \\
\hline & & 7 & 2017 & \multirow[t]{2}{*}{ Rendah } \\
\hline & & 6 & 2016 & \\
\hline \multirow[t]{6}{*}{$\mathbf{i}$} & Saya Mampu Mengelola Waktu Secara & 2 & 2017 & \multirow[t]{2}{*}{ Tinggi } \\
\hline & \multirow[t]{5}{*}{ Efisien } & 4 & 2016 & \\
\hline & & 25 & 2017 & \multirow[t]{2}{*}{ Sedang } \\
\hline & & 21 & 2016 & \\
\hline & & 3 & 2017 & \multirow[t]{2}{*}{ Rendah } \\
\hline & & 5 & 2016 & \\
\hline \multirow[t]{6}{*}{ m } & Saya Menerima Berbagai Kritik Yang & 7 & 2017 & \multirow[t]{2}{*}{ Tinggi } \\
\hline & Diberikan Oleh Orang Lain & 10 & 2016 & \\
\hline & & 21 & 2017 & Sedang \\
\hline & & 10 & 2016 & \\
\hline & & 2 & 2017 & Rendah \\
\hline & & 10 & 2016 & \\
\hline
\end{tabular}


Berdasarkan tabel 3, penguasaan keterampilan (soft skills) dengan kategori sedang pada sebagian besar mahasiswa sebelum PPLSP adalah kemampuan dalam menyelesaikan tugas dengan tepat waktu, sedangkan sebagian besar mahasiswa setelah PPLSP adalah kemampuan dalam memiliki jiwa kepemimpinan tidak otoriter dalam bekerja. Sementara penguasaan keterampilan (soft skills) dengan kategori rendah pada sebagian besar mahasiswa sebelum PPLSP adalah kemampuan dalam menciptakan suasana yang nyaman (tanpa emosional) dalam menyelesaikan konflik, sedangkan pada mahasiswa setelah PPLSP adalah kemampuan dalam menerima berbagai kritik yang diberikan oleh orang lain.

Guru sebagai pemimpin selain dituntut untuk memberikan pengajaran juga dituntut untuk bisa menjadi tauladan bagi peserta didiknya serta mampu menyelesaikan konflik dengan suasana nyaman (tanpa emosional). Sebagian besar mahasiswa sebelum PPLSP belum menguasai kemampuan dalam menciptakan suasana nyaman (tanpa emosional) dalam menyelesaikan konflik, maka dalam tugas kesehariannya dapat dilatih dengan alternatif penyelesaian sebagai berikut: a) duduk bersama, berunding, dan bermusyawarah, b) melihat masalah dengan kepala dingin dan mendiskusikannya, c) bersikap kooperatif agar lebih banyak menemukan titik persamaan (tujuan) dalam penyelesaian konflik, d) tidak selalu "mau menang sendiri" atau "pihak lain harus mengalah". Sebagai seorang pendidik, tunjukkan itikad baik dengan bersedia mengalah terutama ketika konflik sedang berada pada titik klimaks (Yuniaty, 2013).

Sementara itu, mahasiswa setelah PPLSP tidak menguasai kemampuan dalam menerima berbagai kritik dari orang lain. Penting bagi seorang guru untuk memiliki rasa terbuka dalam menerima kritik terutama kritik untuk meningkatkan kualitas performa kerja guru di kelas maupun di luar kelas.

Sebagian besar mahasiswa setelah PPLSP merupakan anggota organisasi. Biasanya seseorang yang mengikuti organisasi sudah terbiasa dengan yang diberikan orang lain, sehingga seharusnya mahasiswa PPLSP mampu untuk menerima berbagai kritik. Hal tersebut mungkin disebabkan masih adanya sikap superior dalam diri mahasiswa setelah PPLSP. Menurut Warsono (2017) sikap superior adalah sikap yang memposisikan dirinya sebagai guru dan menganggap bahwa guru adalah yang paling benar.

\section{Penguasaan Keterampilan (soft skills) Bekerjasama Mahasiswa}

Keterampilan (soft skills) bekerjasama dijabarkan ke dalam 4 item pernyataan dalam kuesioner self-report. Adapun hasil perhitungan dari keempat item pernyataan keterampilan (soft skills) bekerjasama diuraikan tabel 4 .

Tabel 4. Penguasaan Keterampilan (soft skills) Bekerjasama Mahasiswa Prodi PTAg Untuk Menjadi Guru Vokasi di Era Revolusi Industri 4.0

\begin{tabular}{|c|c|c|c|c|c|c|c|c|c|}
\hline & Pernyataan & $\begin{array}{l}\text { Jumlah } \\
\text { (orang) }\end{array}$ & Angkatan & Kategori & & Pernyataan & $\begin{array}{l}\text { Jumlah } \\
\text { (orang) }\end{array}$ & Angkatan & Kategori \\
\hline \multirow[t]{11}{*}{$\mathbf{a}$} & Saya Mampu & 5 & 16.7 & \multirow[t]{2}{*}{ Tinggi } & \multirow[t]{11}{*}{$c$} & \multirow{11}{*}{$\begin{array}{l}\text { Saya } \\
\text { Melakukan } \\
\text { Tindakan } \\
\text { Selama } \\
\text { Situasi Atau } \\
\text { Masalah } \\
\text { Tersebut } \\
\text { Sedang } \\
\text { Berlangsung }\end{array}$} & 2 & 6.7 & \multirow[t]{2}{*}{ Tinggi } \\
\hline & Bekerjasama & 11 & 36.7 & & & & 4 & 13.3 & \\
\hline & Dan & 20 & 66.7 & \multirow[t]{2}{*}{ Sedang } & & & 24 & 80 & \multirow[t]{2}{*}{ Sedang } \\
\hline & Bergotong & 14 & 46.7 & & & & 18 & 60 & \\
\hline & & 5 & 16.7 & \multirow[t]{7}{*}{ Rendah } & & & 4 & 13.3 & \multirow[t]{7}{*}{ Rendah } \\
\hline & Bersama & 5 & 16.7 & & & & 8 & 26.7 & \\
\hline & $\begin{array}{l}\text { Dengan Pihak } \\
\text { Sekolah }\end{array}$ & & & & & & & & \\
\hline & Dalam & & & & & & & & \\
\hline & Melakukan & & & & & & & & \\
\hline & Suatu & & & & & & & & \\
\hline & Kegiatan & & & & & & & & \\
\hline \multirow[t]{10}{*}{ b } & Saya Mampu & 4 & 13.3 & \multirow[t]{2}{*}{ Tinggi } & \multirow[t]{10}{*}{ d } & \multirow{10}{*}{$\begin{array}{l}\text { Saya } \\
\text { Melakukan } \\
\text { Upaya } \\
\text { Percegahan } \\
\text { Agar Situasi } \\
\text { Atau Masalah } \\
\text { Tersebut } \\
\text { Tidak } \\
\text { Kembali } \\
\text { Terjadi }\end{array}$} & 3 & 10 & \multirow[t]{2}{*}{ Tinggi } \\
\hline & Melakukan & 6 & 20 & & & & 9 & 30 & \\
\hline & Tindakan & 21 & 70 & \multirow[t]{2}{*}{ Sedang } & & & 21 & 70 & \multirow[t]{2}{*}{ Sedang } \\
\hline & Antisipasi & 20 & 66.7 & & & & 19 & 63.3 & \\
\hline & Terhadap & 5 & 16.7 & \multirow[t]{6}{*}{ Rendah } & & & 6 & 20 & \multirow[t]{6}{*}{ Rendah } \\
\hline & Suatu Situasi & 4 & 13.3 & & & & 2 & 6.7 & \\
\hline & Atau Masalah & & & & & & & & \\
\hline & & & & & & & & & \\
\hline & & & & & & & & & \\
\hline & & & & & & & & & \\
\hline
\end{tabular}

Dari keempat item pernyataan dalam keterampilan bekerjasama, penguasaan keterampilan (soft skills) dengan kategori sedang pada sebagian besar mahasiswa sebelum PPLSP adalah kemampuan dalam melakukan tindakan selama situasi atau masalah tersebut berlangsung, sedangkan pada sebagian besar mahasiswa setelah PPLSP adalah kemampuan dalam melakukan tindakan antisipasi terhadap suatu situasi atau masalah. Sementara penguasaan keterampilan (soft skills) dengan kategori rendah pada sebagian besar mahasiswa sebelum PPLSP adalah kemampuan dalam 
melakukan upaya pencegahan agar situasi atau masalah tersebut tidak kembali terjadi, sedangkan pada mahasiswa setelah PPLSP adalah kemampuan dalam melakukan tindakan selama situasi atau masalah tersebut sedang berlangsung.

Kemampuan dalam melakukan upaya pencegahan terhadap suatu masalah termasuk ke dalam 5 kompetensi yang harus dipersiapkan guru memasuki era Revolusi Industri 4.0, yakni kompetensi strategi di masa depan (competence in future strategies). Kemampuan ini dapat dikembangkan melalui joint-lecture, joint-research, joint-resources, staff mobility, dan rotasi (Qusthalani dalam Wahyuni, 2018). Joint-research dengan menjalin kerjasama bidang penelitian (penelitian kolaboratif dengan kampus luar negeri), (2) program joint-lecturer (kuliah umum), (3) pertukaran pegawai (Helaluddin dan Wijaya, 2019), lalu rotasi guru (mutasi) dengan tujuan untuk pemerataan kualitas guru.

Sementara itu, mahasiswa setelah PPLSP tidak menguasai kemampuan dalam melakukan tindakan selama masalah tersebut sedang berlangung atau dengan kata lain mahasiswa PPLSP tidak menguasai kemampuan bekerjasama dalam memecahkan masalah padahal guru dikenal sebagai problem solver dalam belajar pendidikan. Hendra (dalam Riofita, 2016) menjabarkan langkah-langkah guru untuk menjadi problem solver melalui kerjasama antara lain: (a) menentukan dan mendefinisikan permasalahan siswa dengan tepat, (b) membangun kesepakatan dengan pihak-pihak yang dianggap harus terlibat dalam penyelesaian masalah, (c) membuat rencana pemecahan masalah dan berbagai macam alternatifnya (d) melakukan simulasi terhadap semua alternatif solusi masalah yang telah dibuat, (e) menentukan solusi dan segera untuk mengimplementasikannya, (f) asumsikan bahwa tidak ada masalah yang tidak bisa diselesaikan.

\section{Penguasaan Keterampilan (soft skills) Berkreativitas Mahasiswa}

Keterampilan (soft skills) berkreativitas dijabarkan ke dalam 6 item pernyataan dalam kuesioner self-report. Adapun hasil perhitungan tersebut diuraikan tabel 5.

Tabel 5. Penguasaan Keterampilan (soft skills) Berkreativitas Mahasiswa Prodi PTAg Untuk Menjadi Guru Vokasi di Era Revolusi Industri 4.0

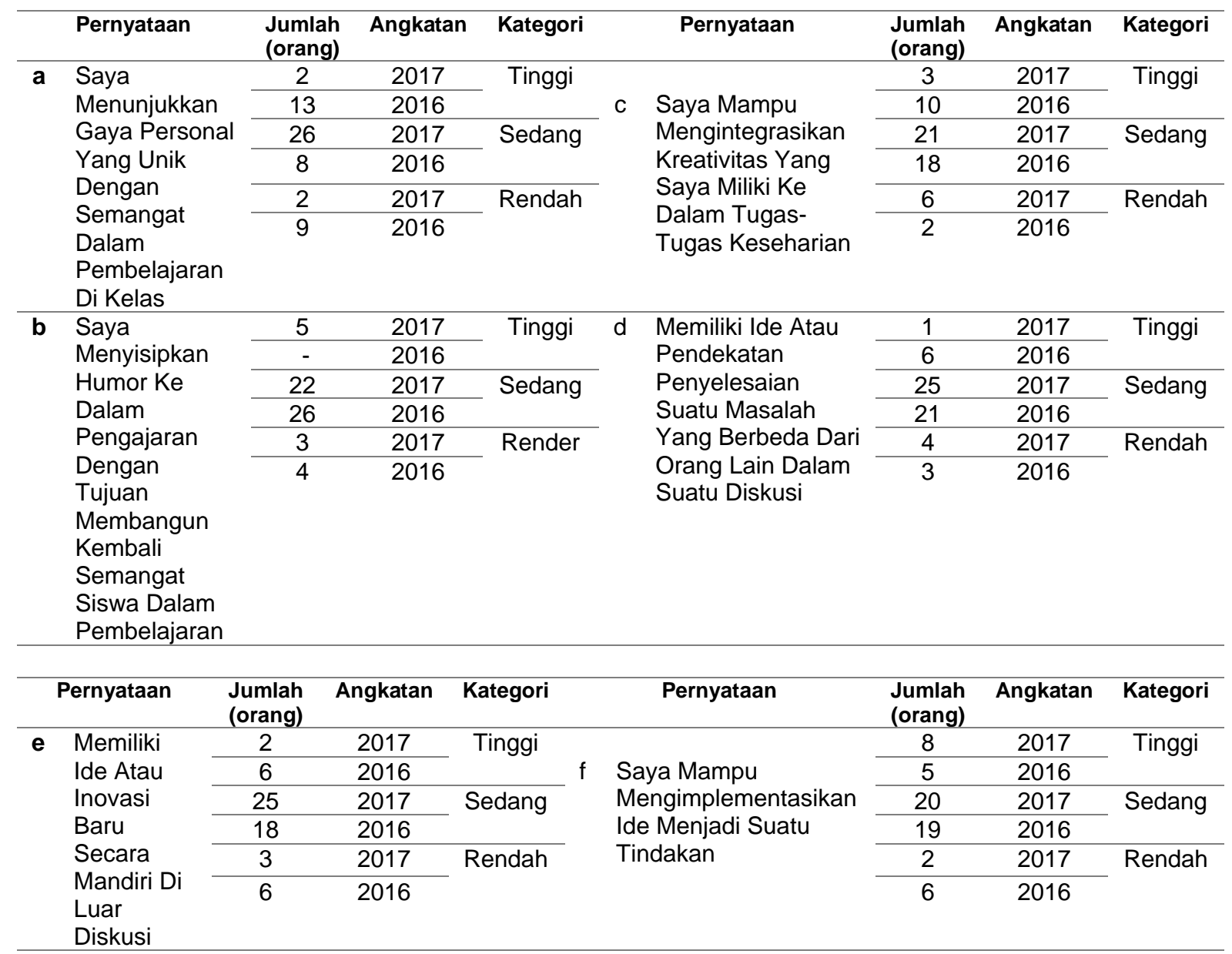


Dalam KBBI, integrasi artinya pembauran hingga menjadi kesatuan yang utuh atau bulat. Mahasiswa sebelum PPLSP tidak menguasai kemampuan dalam mengintegrasikan kreativitas yang dimiliki ke dalam tugas keseharian. Mengitegrasikan kreativitas dalam tugas ke keseharian berarti memadukan kreativitas dalam mengemban tugas sebagai guru, contohnya dalam pembelajaran di kelas. Juhartutik (2011) menemukan penelitian yang mengemukakan bahwa terdapat tiga pendekatan untuk mengintegrasikan kreativitas dalam pembelajaran, yaitu mengembangkan pemikiran kreatif melalui proses pembelajaran, konten ilmu pengetahuan, dan skenario ilmu pengetahuan.

Mahasiswa setelah PPLSP tidak menguasai kemampuan dalam menunjukkan gaya personal yang unik dengan semangat dalam pembelajaran, ini berbanding terbalik dengan kemampuan mahasiswa sebelum PPLSP. Menurut McEwan dan Elaine, K. (2014) guru dengan gaya personal yang unik, membawa drama, semangat, gairah bekerja, humoris, berkharisma, kreatif, dan menyisipkan hal yang baru ke dalam pengajaran merupakan guru yang efektif. Tohir (2016) menegaskan bahwa menjadi guru yang humoris merupakan salah satu syarat agar pembelajaran tidak membosankan.

\section{Penguasaan Keterampilan (soft skills) Memecahkan Masalah}

Keterampilan (soft skills) memecahkan masalah dijabarkan ke dalam 8 item pernyataan dalam kuesioner self-report. Adapun hasil perhitungan dari kedelapan item pernyataan keterampilan (soft skills) memecahkan masalah diuraikan tabel 6.

Tabel 6. Penguasaan Keterampilan (soft skills) Memecahkan Masalah Mahasiswa Prodi PTAg Untuk Menjadi Guru Vokasi di Era Revolusi Industri 4.0

\begin{tabular}{|c|c|c|c|c|c|c|c|c|c|}
\hline & Pernyataan & $\begin{array}{l}\text { Jumlah } \\
\text { (orang) }\end{array}$ & Angkatan & Kategori & & Pernyataan & $\begin{array}{l}\text { Jumlah } \\
\text { (orang) }\end{array}$ & Angkatan & Kategori \\
\hline \multirow[t]{11}{*}{ a } & Saya Mampu & 4 & 2017 & \multirow{2}{*}{ Tinggi } & \multirow[t]{11}{*}{ c } & \multirow{11}{*}{$\begin{array}{l}\text { Saya } \\
\text { Menganggap } \\
\text { Diskusi } \\
\text { Merupakan } \\
\text { Kesempatan } \\
\text { Untuk } \\
\text { Memperluas } \\
\text { Pengetahuan }\end{array}$} & 8 & 2017 & \multirow[t]{2}{*}{ Tinggi } \\
\hline & Mencari & 6 & 2016 & & & & 10 & 2016 & \\
\hline & Alternatif & 18 & 2017 & \multirow[t]{2}{*}{ Sedang } & & & 21 & 2017 & \multirow[t]{2}{*}{ Sedang } \\
\hline & Pemecahan & 19 & 2016 & & & & 12 & 2016 & \\
\hline & Masalah & 8 & 2017 & \multirow[t]{7}{*}{ Rendah } & & & 1 & 2017 & \multirow[t]{7}{*}{ Rendah } \\
\hline & $\begin{array}{l}\text { Dengan } \\
\text { Pemikiran Yang }\end{array}$ & 5 & 2016 & & & & 8 & 2016 & \\
\hline & Logis Dengan & & & & & & & & \\
\hline & Memperhatikan & & & & & & & & \\
\hline & Kelebihan Dan & & & & & & & & \\
\hline & Kekurangan & & & & & & & & \\
\hline & Dari Alternatif & & & & & & & & \\
\hline \multirow{11}{*}{ b } & Saya Mampu & 7 & 2017 & \multirow{2}{*}{ Tinggi } & \multirow{10}{*}{$d$} & \multirow{10}{*}{$\begin{array}{l}\text { Saya } \\
\text { Menganggap } \\
\text { Diskusi } \\
\text { Merupakan } \\
\text { Kesempatan } \\
\text { Untuk } \\
\text { Meningkatkan } \\
\text { Keterampilan } \\
\text { Berpikir Seperti } \\
\text { Penjelasan, } \\
\text { Analisis, Dan } \\
\text { Evaluasi Diskusi }\end{array}$} & 12 & 2017 & \multirow{2}{*}{ Tinggi } \\
\hline & Menyelesaikan & $\frac{1}{3}$ & 2016 & & & & 11 & 2016 & \\
\hline & Masalah & 19 & 2017 & \multirow[t]{2}{*}{ Sedang } & & & 9 & 2017 & \multirow[t]{2}{*}{ Sedang } \\
\hline & Pendidikan & 23 & 2016 & & & & 10 & 2016 & \\
\hline & Dengan Aturan & 4 & 2017 & \multirow[t]{6}{*}{ Rendah } & & & 9 & 2017 & \multirow[t]{6}{*}{ Rendah } \\
\hline & Berbagai & 4 & 2016 & & & & 9 & 2016 & \\
\hline & $\begin{array}{l}\text { Budaya Di } \\
\text { Sekolah Itu }\end{array}$ & & & & & & & & \\
\hline & Berada & & & & & & & & \\
\hline & & & & & & & & & \\
\hline & & & & & & & & & \\
\hline & Pernyataan & Jumlah & Angkatan & Kategori & & Pernyataan & Jumlah & Angkatan & Kategori \\
\hline \multirow[t]{6}{*}{ e } & Saya Mampu & 1 & 2017 & \multirow[t]{2}{*}{ Tinggi } & \multirow[t]{6}{*}{$g$} & \multirow{6}{*}{$\begin{array}{l}\text { Saya Mampu } \\
\text { Memprediksi } \\
\text { Peristiwa Yang } \\
\text { Akan Datang Di } \\
\text { Masa Depan } \\
\text { Berdasarkan } \\
\text { Masalah Yang } \\
\text { Sedang Atau } \\
\text { Telah Dihadapi }\end{array}$} & $\frac{\text { (orang) }}{7}$ & 2017 & \multirow{2}{*}{ Tinggi } \\
\hline & Memecahkan & 6 & 2016 & & & & 4 & 2016 & \\
\hline & Masalah & 22 & 2017 & \multirow[t]{2}{*}{ Sedang } & & & 20 & 2017 & \multirow[t]{2}{*}{ Sedang } \\
\hline & \multirow{3}{*}{$\begin{array}{l}\text { Seputar } \\
\text { Pendidikan } \\
\text { Melalui } \\
\text { Pembelajaran } \\
\text { Di Kelas }\end{array}$} & 19 & 2016 & & & & 23 & 2016 & \\
\hline & & 7 & 2017 & \multirow[t]{2}{*}{ Rendah } & & & 3 & 2017 & Rendah \\
\hline & & 5 & 2016 & & & & 3 & 2016 & \\
\hline & Saya Mampu & 3 & 2017 & Tinggi & $\mathrm{h}$ & Saya Mampu & 5 & 2017 & Tinggi \\
\hline$f$ & Memecahkan & 5 & 2016 & & & Mengemukakan & 6 & 2016 & \\
\hline & Masalah & 24 & 2017 & Sedang & & Pendapat & 19 & 2017 & Sedang \\
\hline & Seputar & 19 & 2016 & & & Berdasarkan & 18 & 2016 & \\
\hline & $\begin{array}{l}\text { Pendidikan } \\
\text { Melalui }\end{array}$ & 3 & 2017 & Rendah & & & 6 & 2017 & Rendah \\
\hline & $\begin{array}{l}\text { Kegiatan } \\
\text { Ekstrakurikuler }\end{array}$ & 6 & 2016 & & & & 6 & 2016 & \\
\hline
\end{tabular}


Dari kedelapan item pernyataan dalam keterampilan memecahkan masalah, penguasaan keterampilan (soft skills) dengan kategori sedang pada sebagian besar mahasiswa sebelum PPLSP adalah kemampuan dalam memecahkan masalah seputar pendidikan melalui kegiatan ekstrakurikuler, sedangkan pada sebagian besar mahasiswa setelah PPLSP adalah kemampuan dalam menyelesaikan masalah pendidikan dengan aturan berbagai budaya di sekolah itu berada serta kemampuan dalam memprediksi peristiswa yang akan datang di masa depan berdasarkan masalah yang sedang atau telah dihadapi. Sementara penguasaan keterampilan (soft skills) dengan kategori rendah pada sebagian besar mahasiswa sebelum dan setelah PPLSP adalah kemampuan dalam menganggap diskusi merupakan kesempatan untuk meningkatkan keterampilan berpikir seperti penjelasan, analisis, dan evaluasi diskusi.

Menurut Prasetyo dan Arsanti (2017) terdapat 2 faktor penghambat dalam diskusi yakni faktor inidvidu dan organisasional. Faktor penghambat individu dalam diskusi diantaranya kemampuan kognitif, kemampuan komunikasi, risiko yang akan dihadapi, motivasi yang rendah, kurangnya kepercayaan diri, dan nilai budaya pada individu. Sedangkan faktor organisational merupakan hambatan di luar individu yang menjadi barriers terjadinya proses diksusi mahasiswa calon guru. Hambatan tersebut berupa kesempatan untuk berdiskusi dalam kelas, sistem penghargaan yang ada, dan lingkungan di sekitar individu. Hal tersebut dapat menghambat mahasiswa dalam sharing of knowledge pada individu dalam suatu diskusi.

\section{Penguasaan Keterampilan (soft skills) Belajar Mahasiswa sebagai calon Guru Vokasional}

Keterampilan (soft skills) belajar dijabarkan ke dalam 12 item pernyataan dalam kuesioner selfreport. Adapun hasil perhitungan dari keduabelas item pernyataan keterampilan (soft skills) belajar diuraikan tabel 7.

Tabel 7. Penguasaan Keterampilan (soft skills) Belajar Mahasiswa Prodi PTAg Untuk Menjadi Guru Vokasi di Era Revolusi Industri 4.0

\begin{tabular}{|c|c|c|c|c|c|c|c|c|c|}
\hline & Pernyataan & $\begin{array}{l}\text { Jumlah } \\
\text { (orang) }\end{array}$ & Angkatan & Kategori & & Pernyataan & $\begin{array}{l}\text { Jumlah } \\
\text { (orang) }\end{array}$ & Angkatan & Kategori \\
\hline \multirow[t]{6}{*}{ a } & \multirow{6}{*}{$\begin{array}{l}\text { Ketika Saya } \\
\text { Merasa Cemas, } \\
\text { Saya Mampu } \\
\text { Mengidentifikasi } \\
\text { Kecemasan Apa } \\
\text { Yang Sedang Saya } \\
\text { Alami }\end{array}$} & 2 & 2017 & \multirow[t]{2}{*}{ Tinggi } & \multirow{6}{*}{$g$} & \multirow{6}{*}{$\begin{array}{l}\text { Saya } \\
\text { Menggunakan } \\
\text { Berbagai Teknik } \\
\text { Untuk } \\
\text { Meningkatkan } \\
\text { Pemahaman Diri } \\
\text { Terhadap Dunia } \\
\text { Pendidikan }\end{array}$} & 3 & 2017 & \multirow[t]{2}{*}{ Tinggi } \\
\hline & & 4 & 2016 & & & & 3 & 2016 & \\
\hline & & 26 & 2017 & \multirow[t]{2}{*}{ Sedang } & & & 23 & 2017 & \multirow[t]{2}{*}{ Sedang } \\
\hline & & 23 & 2016 & & & & 20 & 2016 & \\
\hline & & 2 & 2017 & \multirow[t]{2}{*}{ Rendah } & & & 4 & 2017 & \multirow[t]{2}{*}{ Rendah } \\
\hline & & 3 & 2016 & & & & 7 & 2016 & \\
\hline \multirow[t]{6}{*}{ b } & \multirow{6}{*}{$\begin{array}{l}\text { Saya Mampu } \\
\text { Mengatasi } \\
\text { Kecemasan } \\
\text { Dengan Gaya } \\
\text { Saya Sendiri } \\
\text { (Seperti Menarik } \\
\text { Nafas/Fokus Pada } \\
\text { Tujuan Yang Ingin } \\
\text { Dicapai/Berbagi } \\
\text { Cerita Kepada } \\
\text { Orang Yang }\end{array}$} & 4 & 2017 & \multirow[t]{2}{*}{ Tinggi } & \multirow[t]{6}{*}{$\mathrm{h}$} & \multirow{6}{*}{$\begin{array}{l}\text { Saya Mampu } \\
\text { Mengidentifikasi } \\
\text { Informasi } \\
\text { Penting Yang } \\
\text { Akan Dipelajari } \\
\text { Atau Diteliti }\end{array}$} & 3 & 2017 & \multirow[t]{2}{*}{ Tinggi } \\
\hline & & 6 & 2016 & & & & 5 & 2016 & \\
\hline & & 20 & 2017 & \multirow[t]{2}{*}{ Sedang } & & & 23 & 2017 & \multirow[t]{2}{*}{ Sedang } \\
\hline & & 15 & 2016 & & & & 18 & 2016 & \\
\hline & & 6 & 2017 & \multirow[t]{2}{*}{ Rendah } & & & 4 & 2017 & \multirow[t]{2}{*}{ Rendah } \\
\hline & & 9 & 2016 & & & & 7 & 2016 & \\
\hline \multirow{11}{*}{ c } & \multirow{11}{*}{$\begin{array}{l}\text { Saya Tetap } \\
\text { Memiliki Minat } \\
\text { Yang Tinggi } \\
\text { Terhadap Profesi } \\
\text { Keguruan Di Masa } \\
\text { Kini Dan Masa } \\
\text { Depan }\end{array}$} & 4 & 2017 & \multirow[t]{2}{*}{ Tinggi } & \multirow{11}{*}{ i } & \multirow{11}{*}{$\begin{array}{l}\text { Saya Mampu } \\
\text { Menggunakan } \\
\text { Bahan-Bahan } \\
\text { Pendukung } \\
\text { Untuk } \\
\text { Meningkatkan } \\
\text { Pemahaman } \\
\text { Tentang Materi } \\
\text { Belajar Dan } \\
\text { Profesi } \\
\text { Keguruan }\end{array}$} & 1 & 2017 & \multirow[t]{2}{*}{ Tinggi } \\
\hline & & 5 & 2016 & & & & 6 & 2016 & \\
\hline & & 19 & 2017 & \multirow[t]{2}{*}{ Sedang } & & & 21 & 2017 & \multirow[t]{2}{*}{ Sedang } \\
\hline & & 22 & 2016 & & & & 19 & 2016 & \\
\hline & & 7 & 2017 & \multirow[t]{7}{*}{ Rendah } & & & 8 & 2017 & \multirow[t]{7}{*}{ Rendah } \\
\hline & & 3 & 2016 & & & & 5 & 2016 & \\
\hline & & & & & & & & & \\
\hline & & & & & & & & & \\
\hline & & & & & & & & & \\
\hline & & & & & & & & & \\
\hline & & & & & & & & & \\
\hline \multirow[t]{2}{*}{ d } & Ketika & 2 & 2017 & Tinggi & & & 10 & 2017 & Tinggi \\
\hline & Mendapatkan & 6 & 2016 & & & & 3 & 2016 & \\
\hline
\end{tabular}


Khansa Retno Dewi Kariyanti, Sri Handayani, Mustika Nuramalia Handayani/ EDUFORTECH 6 (2) 2021

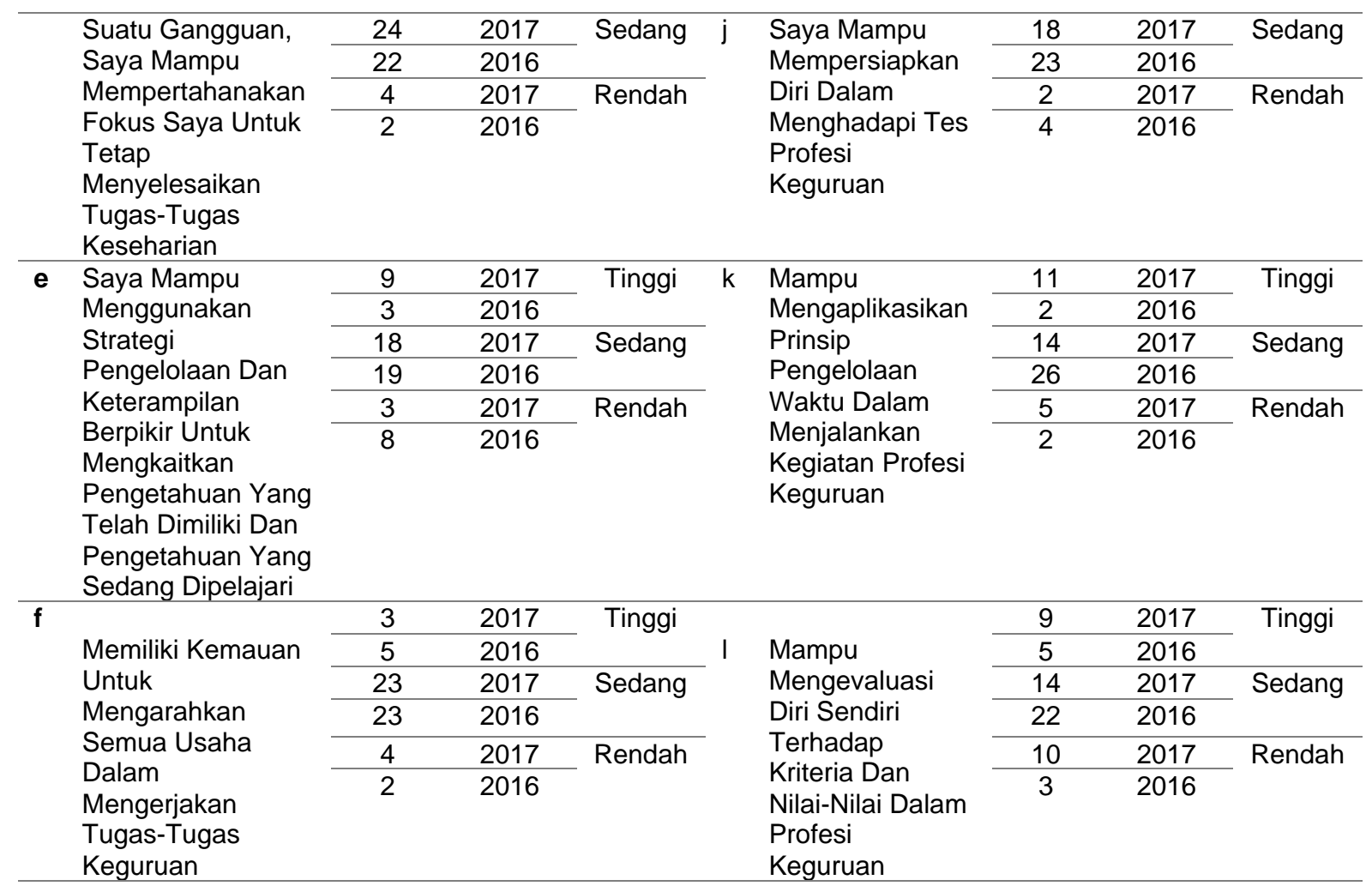

Standar untuk mengukur kinerja guru profesional adalah 4 kompetensi guru (standar keprofesionalan guru) yang menunjukkan sosok utuh guru professional (Raka, 2008 dalam Jaedun, 2009). Jika mahasiswa sebelum PPLSP merasa kesulitan untuk mengevaluasi diri sendiri, maka penilaian dapat dilakukan pengukuran kinerja oleh asesor. Menurut Sukanti (2015) mengevaluasi kinerja guru dapat dilakukan oleh siswa, rekan sejawat, tenaga administrasi, kepala sekolah atau pengawas, termasuk evaluasi diri (self evaluation). Jika tujuan evaluasi untuk kepentingan pengujian kompetensi dan meningkatkan pertumbuhan kinerja guru, maka kegiatan evaluasi melibatkan kepala sekolah atau pengawas.

Mahasiswa setelah PPLSP tidak menguasai kemampuan dalam mengatasi kecemasan dengan gaya sendiri. Kecemasan yang dialami mahasiswa ketika menempuh PPLSP adalah ketika hari pertama mengajar di sekolah, dan hendak ujian PPL. Kecemasan tersebut biasanya berlangsung hanya sekitar 15-30 menit. pengendalian kecemasan dengan gaya sendiri dapat dilakukan dengan relaksasi pernapasan dan latihan otot.

\section{Penguasaan Keterampilan (soft skills) Literasi TIK Mahasiswa Prodi PTAg Untuk Menjadi Guru Vokasi di Era Revolusi Industri 4.0}

Keterampilan (soft skills) literasi TIK dijabarkan ke dalam 11 item pernyataan dalam kuesioner self-report. Adapun hasil perhitungan dari kesebelas item pernyataan keterampilan (soft skills) literasi TIK diuraikan tabel 8.

Tabel 8. Penguasaan Keterampilan (soft skills) Literasi TIK Mahasiswa Prodi PTAg Untuk Menjadi

\begin{tabular}{|c|c|c|c|c|c|c|c|c|c|}
\hline & & & & & & & & & \\
\hline & Pernyataan & $\begin{array}{l}\text { Jumlah } \\
\text { (orang) }\end{array}$ & Angkatan & Kategori & & Pernyataan & $\begin{array}{l}\text { Jumlah } \\
\text { (orang) }\end{array}$ & Angkatan & Kategori \\
\hline \multirow[t]{10}{*}{$\mathbf{a}$} & Saya & 6 & 2017 & \multirow{2}{*}{ Tinggi } & $f$ & \multirow{11}{*}{$\begin{array}{l}\text { Saya Mampu } \\
\text { Memanfaatkan } \\
\text { TIK Untuk } \\
\text { Memahami } \\
\text { Masalah Etika }\end{array}$} & 4 & 2017 & \multirow[t]{2}{*}{ Tinggi } \\
\hline & Menggunakan & 6 & 2016 & & & & 6 & 2016 & \\
\hline & Teknologi & 18 & 2017 & \multirow[t]{2}{*}{ Sedang } & & & 18 & 2017 & \multirow[t]{2}{*}{ Sedang } \\
\hline & Sebagai Alat & 18 & 2016 & & & & 20 & 2016 & \\
\hline & Untuk & 6 & 2017 & \multirow[t]{7}{*}{ Rendah } & & & 8 & 2017 & \multirow{7}{*}{ Rendah } \\
\hline & Melakukan & 6 & 2016 & & & & 4 & 2016 & \\
\hline & $\begin{array}{l}\text { Kegiatan } \\
\text { Pendidikan }\end{array}$ & & & & & & & & \\
\hline & Dan Atau & & & & & & & & \\
\hline & Untuk & & & & & & & & \\
\hline & Melakukan & & & & & & & & \\
\hline & Riset & & & & & & & & \\
\hline \multirow[t]{2}{*}{ b } & Saya & 2 & 2017 & \multirow[t]{2}{*}{ Tinggi } & \multirow[t]{2}{*}{$g$} & Memiliki & 1 & 2017 & \multirow[t]{2}{*}{ Tinggi } \\
\hline & Menggunakan & 8 & 2016 & & & Pengetahuan & 7 & 2016 & \\
\hline
\end{tabular}




\begin{tabular}{|c|c|c|c|c|c|c|c|c|c|}
\hline & Teknologi & 25 & 2017 & Sedang & & Tentang Cara & 24 & 2017 & Sedang \\
\hline & Sebagai Alat & 13 & 2016 & & & Mengoperasikan & 20 & 2016 & \\
\hline & Untuk & 3 & 2017 & Rendah & & Perangkat Lunak & 5 & 2017 & Rendah \\
\hline & $\begin{array}{l}\text { Mengatur } \\
\text { Kegiatan } \\
\text { Pendidikan Di } \\
\text { Sekolah }\end{array}$ & 9 & 2016 & & & $\begin{array}{l}\text { Yang Digunakan } \\
\text { Dunia } \\
\text { Pendidikan }\end{array}$ & 3 & 2016 & \\
\hline C & Saya & 3 & 2017 & Tinggi & $\mathrm{h}$ & Saya Mampu & 5 & 2017 & Tinggi \\
\hline & Menggunakan & 6 & 2016 & & & Memimpin & 6 & 2016 & \\
\hline & Teknologi & 24 & 2017 & Sedang & & Proyek Penelitan & 15 & 2017 & Sedang \\
\hline & Sebagai Alat & 22 & 2016 & & & Milik Sendiri & 22 & 2016 & \\
\hline & Untuk & 3 & 2017 & Rendah & & & 10 & 2017 & Rendah \\
\hline & $\begin{array}{l}\text { Mengevaluasi } \\
\text { Pendidikan }\end{array}$ & 2 & 2016 & & & & 2 & 2016 & \\
\hline d & Saya & 9 & 2017 & Tinggi & $\mathrm{i}$ & Saya Mampu & 3 & 2017 & Tinggi \\
\hline & Menggunakan & 8 & 2016 & & & Memimpin & 6 & 2016 & \\
\hline & Teknologi & 17 & 2017 & Sedang & & Proyek Penelitan & 24 & 2017 & Sedang \\
\hline & Sebagai Alat & 13 & 2016 & & & Peserta Didik & 23 & 2016 & \\
\hline & Untuk & 4 & 2017 & Rendah & & & 3 & 2017 & Rendah \\
\hline & $\begin{array}{l}\text { Berkomunikasi } \\
\text { Dalam Bidang } \\
\text { Pendidikan }\end{array}$ & 9 & 2016 & & & & 1 & 2016 & \\
\hline e & Saya Mampu & 6 & 2017 & Tinggi & j & Saya Mampu & 2 & 2017 & Tinggi \\
\hline & Memanfaatkan & 6 & 2016 & & & Mengidentifikasi & 4 & 2016 & \\
\hline & TIK Untuk & 20 & 2017 & Sedang & & Strategi Sukses & 24 & 2017 & Sedang \\
\hline & Memahami & 20 & 2016 & & & Dalam Mengajar & 22 & 2016 & \\
\hline & Masalah Sosial & 4 & 2017 & Rendah & & Di Ruang Kelas & 4 & 2017 & Rendah \\
\hline & & 4 & 2016 & & & & 4 & 2016 & \\
\hline
\end{tabular}

Mahasiswa sebelum PPLSP tidak menguasai kemampuan dalam memimpin proyek sendiri padahal sebagian besar mahasiswa PPLSP merupakan mahasiswa semester 6 dan 7 yang sudah melalui mata kuliah Riset Agroindustri (Proyek Akhir). Hal ini mungkin dapat disebabkan karena mahasiswa kurang memahami prinsip dari manajemen proyek yang meliputi penerapan pengetahuan, keterampilan menggunakan perangkat atau alat-alat teknik pada saat aktivitas proyek, dimana prinsip tersebut merupakan syarat dan kebutuhan proyek agar proyek terpenuhi (Teguh dan Sudiadi, 2015).

Mahasiswa setelah PPLSP tidak menguasai kemampuan dalam menggunakan teknologi sebagai alat untuk mengatur kegiatan pendidikan dan berkomunikasi dalam bidang pendidikan. Dikutip dari Munir (2009) kompetensi TIK yang harus dimiliki guru adalah: a) mengetahui, menguasai, dan mengerti kurikulum TIK, b) mengetahui dan mahir dalam operasi komputer dan perangkat lain TIK yang menunjang, c) memiliki kemampuan dalam pemilihan software pengajaran, d) mengetahui teknik-teknik pengajaran menggunakan komputer, e) memiliki pemahaman tentang etika, hukum, dan peraturan keselamatan, dan f) peka terhadap teknologi terkini dalam dunia pendidikan.

\section{Penguasaan Keterampilan (soft skills) Kejujuran}

Keterampilan (soft skills) kejujuran dijabarkan ke dalam 3 item pernyataan dalam kuesioner self-report. Adapun hasil perhitungan dari ketiga item pernyataan keterampilan (soft skills) kejujuran diuraikan tabel 9.

Tabel 9. Penguasaan Keterampilan (soft skills) Kejujuran Mahasiswa Prodi PTAg Untuk Menjadi Guru Vokasi di Era Revolusi Industri 4.0

\begin{tabular}{|c|c|c|c|c|c|c|c|c|}
\hline & Pernyataan & $\begin{array}{l}\text { Jumlah } \\
\text { (orang) }\end{array}$ & Angkatan & Kategori & Pernyataan & $\begin{array}{l}\text { Jumlah } \\
\text { (orang) }\end{array}$ & Angkatan & Kategori \\
\hline \multirow[t]{9}{*}{$\mathbf{a}$} & Saya Mampu & 5 & 2017 & \multirow[t]{2}{*}{ Tinggi } & \multirow{9}{*}{ Tian } & 4 & 2017 & \multirow[t]{2}{*}{ Tinggi } \\
\hline & Untuk & 5 & 2016 & & & 7 & 2016 & \\
\hline & Menunjukkan & 19 & 2017 & \multirow[t]{2}{*}{ Sedang } & & 22 & 2017 & \multirow[t]{2}{*}{ Sedang } \\
\hline & Konsistensi & 20 & 2016 & & & 19 & 2016 & \\
\hline & Antara & 6 & 2017 & \multirow[t]{5}{*}{ Rendah } & & 4 & 2017 & \multirow[t]{5}{*}{ Rendah } \\
\hline & $\begin{array}{l}\text { Perkataan dan } \\
\text { Perbuatan }\end{array}$ & 5 & 2016 & & & 4 & 2016 & \\
\hline & Dalam Tindakan & & & & & & & \\
\hline & Maupun & & & & & & & \\
\hline & Pekerjaan & & & & & & & \\
\hline
\end{tabular}


Penguasaan keterampilan (soft skills) dengan kategori rendah pada sebagian besar mahasiswa sebelum PPLSP adalah kemampuan dalam menunjukkan konsistensi antara perkataan dan perbuatan dalam tindakan maupun pekerjaan, sedangkan pada mahasiswa setelah PPLSP adalah kemampuan dalam berperilaku yang mencerminkan ketakwaan dan akhlak mulia berdasarkan ajaran yang dianut. Konsistensi termasuk ke dalam kompetensi kepribadian yang diatur dalam Peraturan Pemerintah No. 19 Tahun 2005 tentang Standar Nasional Pendidikan Pasal 38. Guru yang efektif memiliki komitmen untuk meyakinkan para siswanya untuk belajar. Selain itu, komitmen menjadi pembeda antara guru profesional dengan guru tidak professional serta pembeda antara guru yang berdedikasi dengan guru yang tidak berdedikasi (Prayitno, 2015), namun di samping itu komitmen memerlukan konsistensi. Sikap konsisten adalah sikap teguh pendirian dan selalu konsekuen. Seseorang yang memiliki niat dan keyakinan yang kuat tidak akan goyah menghadapi rintangan, tantangan, dan hambatan (Wahyono dan Toruan, 2010).

\section{Penguasaan Keterampilan (soft skills) Percaya Diri Mahasiswa}

Keterampilan (soft skills) percaya diri dijabarkan ke dalam 7 item pernyataan dalam kuesioner self-report. Adapun hasil perhitungan dari ketujuh item pernyataan keterampilan (soft skills) percaya diri diuraikan tabel 10

Tabel 10. Penguasaan Keterampilan (soft skills) Percaya Diri Mahasiswa Prodi PTAg Untuk Menjadi Guru Vokasi di Era Revolusi Industri 4.0

\begin{tabular}{|c|c|c|c|c|c|c|c|c|c|}
\hline & Pernyataan & $\begin{array}{l}\text { Jumlah } \\
\text { (orang) }\end{array}$ & Angkatan & Kategori & & Pernyataan & $\begin{array}{l}\text { Jumlah } \\
\text { (orang) }\end{array}$ & Angkatan & Kategori \\
\hline \multirow[t]{6}{*}{ a } & \multirow{6}{*}{$\begin{array}{l}\text { Saya } \\
\text { Menyadari } \\
\text { Akan } \\
\text { Kemampuan } \\
\text { Yang Saya } \\
\text { Miliki }\end{array}$} & 5 & 2017 & \multirow[t]{2}{*}{ Tinggi } & \multirow{6}{*}{$d$} & \multirow{6}{*}{$\begin{array}{l}\text { Saya Meyakini } \\
\text { Kapasitas Saya } \\
\text { Untuk } \\
\text { Menyelesaikan } \\
\text { Suatu Tugas } \\
\text { Untuk Memilih } \\
\text { Pendekatan } \\
\text { Yang Objektif } \\
\text { Dalam } \\
\text { Pemecahannya }\end{array}$} & 3 & 2017 & \multirow[t]{2}{*}{ Tinggi } \\
\hline & & 9 & 2016 & & & & 6 & 2016 & \\
\hline & & 21 & 2017 & \multirow[t]{2}{*}{ Sedang } & & & 19 & 2017 & \multirow[t]{2}{*}{ Sedang } \\
\hline & & 18 & 2016 & & & & 22 & 2016 & \\
\hline & & 4 & 2017 & \multirow[t]{2}{*}{ Rendah } & & & 8 & 2017 & \multirow[t]{2}{*}{ Rendah } \\
\hline & & 3 & 2016 & & & & 2 & 2016 & \\
\hline \multirow[t]{6}{*}{ b } & Saya Percaya & 3 & 2017 & \multirow[t]{2}{*}{ Tinggi } & \multirow[t]{6}{*}{ e } & \multirow{6}{*}{$\begin{array}{l}\text { Saya } \\
\text { Menampilkan Diri } \\
\text { Sebagai Pribadi } \\
\text { Yang Dewasa, } \\
\text { Arif, dan } \\
\text { Berwibawa }\end{array}$} & 4 & 2017 & \multirow[t]{2}{*}{ Tinggi } \\
\hline & Bahwa Saya & 6 & 2016 & & & & 3 & 2016 & \\
\hline & Memiliki & 22 & 2017 & \multirow[t]{2}{*}{ Sedang } & & & 19 & 2017 & \multirow[t]{2}{*}{ Sedang } \\
\hline & Kemampuan & 17 & 2016 & & & & 23 & 2016 & \\
\hline & Yang & 5 & 2017 & \multirow[t]{2}{*}{ Rendah } & & & 7 & 2017 & \multirow[t]{2}{*}{ Rendah } \\
\hline & $\begin{array}{l}\text { Memadai } \\
\text { Untuk } \\
\text { Menjadi Guru } \\
\text { Vokasi Di Era } \\
\text { RI } 4.0\end{array}$ & 7 & 2016 & & & & 4 & 2016 & \\
\hline \multirow[t]{6}{*}{ c } & Saya Berani & 4 & 2017 & \multirow[t]{2}{*}{ Tinggi } & \multirow[t]{6}{*}{$f$} & \multirow{6}{*}{$\begin{array}{l}\text { Saya Memiliki } \\
\text { Rasa Bangga } \\
\text { Menjadi Guru }\end{array}$} & 5 & 2017 & \multirow[t]{2}{*}{ Tinggi } \\
\hline & Menggunakan & 9 & 2016 & & & & 7 & 2016 & \\
\hline & Dan & 24 & 2017 & \multirow[t]{2}{*}{ Sedang } & & & 19 & 2017 & \multirow[t]{2}{*}{ Sedang } \\
\hline & Menunjukkan & 15 & 2016 & & & & 14 & 2016 & \\
\hline & Kepercayaan & 2 & 2017 & \multirow[t]{2}{*}{ Rendah } & & & 6 & 2017 & \multirow[t]{2}{*}{ Rendah } \\
\hline & $\begin{array}{l}\text { Diri Saya Di } \\
\text { Sekolah }\end{array}$ & 6 & 2016 & & & & 9 & 2016 & \\
\hline
\end{tabular}

Sebagian besar mahasiswa sebelum PPLSP tidak menguasai kemampuan dalam meyakini kapasitas diri untuk menyelesaikan suatu tugas untuk memilih pendekatan yang objektif dalam pemecahannya. Penyelesaian masalah menggunakan pendekatan yang objektif berarti menyelesaikan masalah dengan mengkaji, mencari tahu sebab dan akibat, serta alternatif penyelesaiannya dengan pemikiran kritis. Yakin akan kapasitas diri untuk menyelesaikan suatu masalah merupakan pengertian dari percaya diri. Tidak mampu meyakini diri untuk menyelesaikan suatu masalah berarti mahasiswa tersebut memiliki rasa percaya diri yang rendah.

Masalah percaya diri dapat diatasi melalui hipnoself dan journal writing. Penggunaan teknik hipnoself dapat memberikan kemudahan mahasiswa dalam memberikan sugesti dan motivsi diri untuk dapat lebih yakin dalam membangun rasa percaya diri dalam diri mahasiswa (Yuangga dkk., 2020). Selain hipnoself, upaya yang dapat dilakukan dengan mengikuti terapi journal writing yaitu yaitu terapi menulis atau konseling melalui tulisan untuk mengekspresikan emosi. Journal writing terbukti dapat meningkatkan percaya diri. Metode journal writing terdiri dari menulis permasalahan yang dihadapi, menyusun permasalahan tersebut secara sistematis, lalu mengubah pengalaman negatif menjadi 
pengalaman positif dan diskusi (Indrajat, 2013). Mahasiswa setelah PPLSP memiliki kemampuan yang rendah akan rasa bangga menjadi guru. Hal ini disebabkan karena profesi guru masih dipandang sebelah mata oleh di kalangan masyarakat. Sebagai mahasiswa calon guru, sudah seharusnya bangga menjadi seorang guru karena pekerjaan guru adalah mendidik.

Sikap bangga menjadi guru berpangaruh terhadap konsistensi seperti konsisten dalam bertindak sesuai dengan norma hukum, agama, maupun sosial. Guru tersebut juga mampu menunjukkan kemandirian sebagai pendidik dan memiliki etos kerja yang tinggi. Jika guru tidak bangga terhadap profesinya, maka guru tersebut sulit maju dan berkembang. Cara untuk bangga menjadi guru adalah dengan memenuhi kompetensi kepribadian yang telah disebutkan pada bab sebelumnya yaknik mencerminkan kepribadian yang mantap, stabil, dewasa, arif, berwibawa, menjadi teladan bagi peserta didik, dan berakhlak mulia (Mulyana, 2010). Selain itu, rasa bangga menjadi guru dapat ditanamkan dengan meyakini diri mampu untuk menjalankan tugas menjadi guru, sehingga masyarakat semakin memahami begitu berat dan mulianya pekerjaan guru (Oktradiksa, 2012).

\section{KESIMPULAN}

Berdasarkan hasil penelitian, penguasaan soft skills mahasiswa Prodi Pendidikan Teknologi Agroindustri sebagai calon guru vokasional di era revolusi industri 4.0 berada pada kategori sedang, sehingga perlu adanya peningkatan penguasaan keterampilan (soft skills) pada beberapa indikator keterampilan (soft skills).

\section{DAFTAR PUSTAKA}

Hanief, Y.N. Dan Himawanto, W. (2017). Statistik Pendidikan.Yogyakarta: Deepublish.

Haryati, S. (2015). "Upaya Meningkatkan Soft Skill Mahasiswa Di Perguruan Tinggi". Seminar IImiah Semesteran Kopri Sub Unit Kopertis Wilayah Vi Jawa Tengah Di Magelang. Universitas Tidar. Helaluddin Dan Wijaya, H. (2019). "Pengembangan Kompetensi Pendidik di Perguruan Tinggi dalam Menyongsong Era Revolusi Industri 4.0". Seminar Nasional Pangan, Teknologi, dan Entrepreneurship "Eksplorasi Sumberdaya Alam Hayati Indonesia Berbasis Entrepreneurship di Era Revolusi Industri 4.0" (HIm. 417). Makassar: Universitas Fajar.

Indrajat, A.Y. (2013). Peningkatan Percaya Diri Melalui Metode Journal Writing Pada Siswa Kelas XI SMK N 1 Depok. (Skripsi). Universitas Negeri Yogyakarta, Yogyakarta.

Jaedun, A. (2009). "Evaluasi Kinerja Profesional Guru". Makalah Refleksi Profesi Guru Bersertifikat Profesional (HIm. 13). Yogyakarta: Universitas Negeri Yogyakarta.

Janawi. (2011). Kompetensi Guru Citra Guru Profesional. Bandung: Alfabeta.

Joshi, M. (2017). Soft Skills. $1^{\text {st }}$ Edition. Bangalore: Senior Trainer Acharya Institute of English \& Foreign Languages.

Juhartutik. (2011). Menjadi Guru Matematika Kreatif dan Berwawasan Pendidikan Karakter. Jurnal Matematia Kreatif-Inovatif, 2(1), HIm. 16. D: https://doi.org/10.15294/kreano.v2i1.1242

Lase, D. (2019). "Pendidikan Di Era Revolusi Industri 4.0". Jctes, 1 (1), HIm. 28-43.

Mulyana, A.Z. (2010). Rahasia Menjadi Guru Hebat: Memotivasi Diri Menjadi Guru Luar Biasa. Jakarta: Grasindo.

Munir. (2009). Kerangka Kompetensi Tik Bagi Guru. Bandung: Alfabeta.

Nuryani. (2016). Penerapan Kesantunan Berbahasa dalam Kegiatan Pembelajaran. UIN Syarif Hidayatullah, Jakarta.

Oktradiksa, A. (2012). "Pengembangan Kualitas Kepribadian Guru”. Nadwa: Jurnal Pendidikan Agama Islam, 6(2), HIm. 232.

Peraturan Menteri Pendidikan Nasional Nomor 16 Tahun 2007. (2007). Standar Kualifikasi Akademik dan Kompetensi Guru. [Online]. Diakses Dari : http://vervalsp.data.kemdikbud.go.id/prosespembelajaran/file/permendiknas\%20no\%2016\%20t ahun\%202007.pdf

Prasetyo, Y.A.B. dan Arsanti, T.A. (2017). "Sharing Of Knowledge: Hambatan Keterlibatan Mahasiswa dalam Diskusi". Jurnal Maksipreneur, 7(1), HIm. 1-17.

Riofita, H. (2016). Bentuk Peranan Guru dalam Memberikan Pendidikan Kepemimpinan. Potensia: Jurnal Kependidikan Islam, 2(1), HIm. 97. DOI: http://dx.doi.org/10.24014/potensia.v2i1.2533

Sardi, S. (2011). Upaya Peningkatan Kompetensi Profesional Guru Sekolah Kejuruan. Prosiding. Pedagogika Fip Universitas Negeri Gorontalo. 
Sendana, A.K., Dan Tandikombong, M. (2019). Faktor-Faktor yang Mempengaruhi Keahlian Komunikasi Bagi Guru. Jurnal Kip, 8 (2), HIm. 9-19. DOI: https://doi.org/10.0901/jkip.v8i2.791

Teguh, R. Dan Sudiadi. (2015). Manajemen Proyek. Sekolah Tinggi Manajemen Informatika GI MDPP, Palembang.

Tohir, M. (2016). Menjadi Guru Idaman Siswa. [Online]. Diakses dari: http://pasca.unej.ac.id/menjadiguru-idaman-siswa/

Prayitno, E. (2015). "Konsistensi dan Komitemen Guru dalam Mencetak Generasi Emas”. Jurnal Saung Guru, 3(7), hlm. 235-242.

Undang-Undang Republik Indonesia No. 14 Tahun 2005. Guru dan Dosen. [Online]. Diakses dari: http://sumberdaya.ristekdikti.go.id/wp-content/uploads/2016/02/uu-nomor-14-tahun-2005-ttgguru-dan-dosen.pdf

Wagiran. (2013). "Model Penguatan Soft Skills dalam Mewujudkan Calon Guru Kejuruan Profesional Berkarakter". Jurnal Kependidikan, 7 (2), HIm. 199-217.

Wagiran, Munadi, S. Dan Aw Fathudin, S. (2014). "Pengembangan Model Penguatan Soft Skills dalam Mewujudkan Calon Guru Kejuruan Profesional Berkarakter”. Jurnal Kependidikan, 44 (1), HIm. 92-102.

Wagiran, Pardjono, Suyanto, W., Sofyan, H., Soenarto, S, And Yudantoko,

A.

(2019). "Competencies Of Future Vocational Teachers: Perspective Of In-Service Teachers And Educational Experts". Cakrawala Pendidikan, 38 (2), HIm. 387-397.

Wahyuni, D. (2018). Peningkatan Kompetensi Guru Menuju Era Revolusi Industri 4.0. Jakarta: Pusat Penelitian Badan Keahlian RI.

Warsono, W. (2017). Guru: Antara Pendidik, Profesi, dan Aktor Sosial. The Journal of Society \& Media, 1(1), HIm. 1-10. DOI: http://dx.doi.org/10.26740/jsm.v1n1.p1-10

Widarto. (2011). Pengembangan Soft Skills Mahasiswa Pendidikan Vokasi Melalui Clop-Work. Cetakan Pertama. Yogyakarta: Paramitha Publishing.

Ye-Weon Jeon, Jinkwan Kim, Whayoung Choi, Dr. Seung-II Na. (2017). "Developing The Competencies of Vocational Teachers in The Age of 4th Industrial Revolution". 13th Aasvet International Conference, HIm. 93-93.

Yuangga Dkk. (2020). "Efektivitas Penggunaan Metode Hipnoself dalam Meningkatkan Kepercayaan Diri Mahasiswa Di STIKES Jendral Ahmad Yani Cimahi". Jurnal Pengabdian Pada Masyarakat, 2(1), HIm.62-66. DOI: https://doi.org/10.32672/btm.v2i1.2105

Yuniaty, D. (2013). Peran Pimpinan dalam Menyelesaikan Konflik di Organisasi. (Tugas Akhir). Universitas Negeri Yogyakarta, Yogyakarta. 